the rapidly decreasing area of farm land. The question which the geographer, and the planner, may ask is, "Which is the best and most economic use of this land, considered from the national point of view-for houses or crops ?"

Lastly, Dr. R. A. Pelham urged a better appreciation of traditional building styles and materials in the development particularly of rural areas, in order that such "incongruous atrocities" as rows of red brick houses on the edge of Cotswold towns and villages might be avoided. It is feared, however, that this is an age in which utility and cheapness are more often considered than the rsthetic, and it is after all much cheaper and easier to build with mass-produced bricks than with elaborately prepared stone.
Apart from a highly entertaining and unbiased lantern lecture on South Russia and the Caucasus by Sir John Russell, and a fascinating biological intruduction to the study of landscape from Prof. H. H. Swinnerton, the remaining items in the Conference dealt mainly with educational subjects, ranging from the conception of geographical ideas by school-children to the conception of examination questions by examiners, and from the study of local geography by observation to the study of far-off lands by corresponding with the officers of 'tramp' ships. A lengthy report of a committee of the Association which has been studying world natural regions was also submitted and discussed; the report has been published in full in the December 1937 issue of Geography.
S. H. Beaver.

\title{
Prize Awards for I937 of the Paris Academy of Sciences
}

$\mathrm{A}^{\mathrm{T}}$ $\mathrm{T}$ the annual public meeting held on December 20 last the president announced the prizes and grants awarded in 1937 as follows :

Mathematics. The Francour Prize to Jean Leray, for his work on mathematical analysis.

Mechanics. The Montyon Prize to Lucien Malavard, for his electrical apparatus for the rapid calculation of the distribution of hydrodynamic circulations. The Poncelet Prize to Joseph Bethenod, for his work on mechanics and electricity. The Pierson-Perrin Prize to Léon Brillouin, for the whole of his work, especially for his contributions to the development of quantum mechanics.

Astronomy. The Lalande Prize to Michel Giaco. bini, for his work on stellar astronomy and comets. The Benjamin Valz Prize to Maurice Burgaud, for his work on terrestrial magnetism in China. The G. de Pontecoulant Prize to Henri Roure, for his work on planetary perturbations.

Geography. The Gay Prize to Jean Vignal, for his work on the accuracy of a method of levelling. The Tchihatchef Prize to Etienne Bruzon, for his travels, work and publications relating to the climate of Indo-China. The Binoux Prize to Raoul Goudey and Jean Lagrula, for their gravimetric observations made in France and Northern Africa. The Alexandre Givry Prize to Henri Legrand, for the whole of his hydrographical work in France and its colonies.

Navigation. The Plumey Prize to Roger Brard, for his studies on screw propellers.

Physics. The Kastner-Boursault Prize to Bernard Decaux, for his work on the applications of piezoelectric quartz to chronometry. The Gaston Planté Prize to Jean Bernamont, for his studies on the fluctuations of electrical resistances. The François Hébert Prize to Paul Couderc, for his work on astronomy. The Henri de Parville Prize to Paul Lainé, for his researches on the magnetic and magnetooptic properties of liquefied gases. The Hughes Prize to Paul Soleillet, for his work on the structure of light. The Clément-Félix Foundation to Etienne Vassy, for his work on atmospheric ozone.

Chemistry. The Montyon Prize (Unhealthy Trades) to Roger Renaud, for his work on gas masks. The Jecker Prize to Gustave Vavon, for his work on catalytic hydrogenation and the stereochemistry of the cyclic compounds. The Cahours Foundation to
Georges Laude, for his work on the synthesis of cyanic acid. The Paul Marguerite de la Charlonie Prize to Georges Darzens, for his work in organic chemistry. The Berthelot Prize to Jacques Parrod, for his researches on the synthesis of hydrocyanic acid. The Houzeau Prize to Marius Picon, for his work on sulphides and camphocarbonates. The Charles Adam Girard Foundation to Georges Brooks, for his researches in biological chemistry.

Mineralogy and Geology. The Delesse Prize to Mlle. Simonne Caillère, for her work on the minerals of the serpentine group. The Victor Raulin Prize to Mlle. Henriette Alimen, for her studies on the Stampian of the Paris basin.

Botany. The Desmazières Prize to Robert Potier de La Varde, for his work entitled "Mousses du Gabon". The Montagne Prize to Marius Chadefaud, for his work on Algæ. The Jean Thore Prize to Emile Chemin, for his biological researches on certain Algæ. The de la Fons Mélicocq Prize to Maurice Bouly de Lesdain, for his work entitled "Graminées indigènes et adventices des environs de Dunkerque". The de Coincy Prize to Raymond Benoist, for work in systematic botany in tropical regions.

Anatomy and Zoology. The Cuvier Prize to Paul Chabanaud, for the whole of his work. The Savigny Foundation to Henri Heim de Balsac, for his book on the mammals and birds of northern Africa.

Medicine and Surgery. Montyon Prizes to Emile Césari and Paul Boquet (2,500 franes), for their researches on the antigens of snake poisons and the antibodies of the sera; Michel Salmon (2,500 franos), for his book on the arteries of the skin; Jean Vague (2,500 franes), for his book "Les Hépatonephrites aiguës". Honorable Mentions (1,500 francs) to Ram Kumar Goyal, for his contribution to the study of the Streptothriceæ ; to Eugène Saint-Jacques, for his work on injections of animal charcoal in various diseases; and to Jean Terracol, for his book on the diseases of the nasal fossa. The Barbier Prize to P. Emile Weil, Paul Isch Wall and Mme. Suzanne Perlès, for their book on the puncture of the spleen. The Bréant Prize to Georges Girard and Jean Robic, for their work on the application to man of a new vaccine against plague. The Godard Prize to Gaston Gros, for his memoir on sexual endocrinology. The Mège Prize to Georges Curasson, for his treatise on 
veterinary pathology. The Bellion Prize to Jacques Vialle, Chevalier Jackson and Chevalier L. Jackson, for their memoir on bronchoscopy in bronchopulmonary affections. The Argut Prize to Jean Braine and Raymond Rivoire, for their book on the surgery of the parathyroid glands. The Charles Bouchard Foundation to Maurice Doladilhe, for his studies on the properties of the blood serum. The Jean Dagnan-Bouveret Prize to Michel Weinberg, for his memoir on the anærobic micro-organisms.

Cancer and Tuberculosis. The Roy-Vaucouloux Foundation to Eugene Wollman, for his work on the nature of malignant tumours. The Louise Darracq Prize to Mme. Nadine Dobrovolskaia-Zavadskaia, for work on cancer. The Henriette Régnier Foundation to Robert Broca, for work on tuberculosis.

Physiology. The Montyon Prize to Mlle. Eliane Le Breton, for her memoir on the physiological signification of the oxidation of ethyl alcohol in the organism. The Pourat Prize to Georges Morin, for his work on the intestinal automatism of the vertebrates and its regulation. The Philipeaux Prize to Jean Roche, for his physiological and biological researches on the respiratory pigments. The Fanny Emden Prize between André Tournade (2,000 francs), for researches in experimental physiology, and Raoul Lecoq (1,000 francs), for researches on the $B$ vitamins.

Statistics. Montyon Prizes to Mlle. Dagmare Weinberg (1,000 francs), for her work on the correction of examination papers; Adolphe J Jesage and Marcel Moine (1,000 francs), for their study on infant mortality during the first year. A Mention (500 francs) to Marcel Luc-Vernon, for his studies on the science of values applied to bookkeeping and the statistics of undertakings.

History and Philosophy of Science. The Binoux Prize to Cornelis de Waard, for his contribution to the edition of the correspondence of Père Marin Mersenne.

Works of Science. The Henri de Parville Prize to the Association de la Presse de l'Institut et des Sociétés Savantes.

Medals. The Berthelot Medal to Roger Renaud and to Jacques Parrod.

General Prizes. The Prize founded by the State to Gaston Delépine, for the whole of his palæontological and geological work. The Alhumbert Prize to (the late) Fernand Jacquet, for his researches on the stratigraphy of Senegal and Mauritania. The Bordin Prize to Georges Darmois, for his work on the calculus of probabilities. The Lallemand Prize to Jean Delay, for his work entitled "Les Astéréognosies. Pathologie du toucher". The Petit d'Ormoy Prize (Mathematical Sciences) to Paul Lévy, for the whole of his mathematical work, (Natural Sciences) to Emile Roubaud, for the whole of his entomological and biological work. The Saintour Prize to André Marchaud, for his work on geometry. The Lonchampt Prize to Lazare Silberstein, for the whole of his work on the importance of sulphur in plants and animals. The Wilde Prize to René Lucas, for his work on transversal waves in liquids. The Gustave Roux Prize to Stanislas Goldsztaub, for his work on the crystalline structure of the natural hydrated iron oxides. The Thorlet Prize to Paul Dorveaux. The Marquet Prize to Charles Joyeux, for the whole of his helminthological studies. The Général Muteau Prize to Gaston Ramon, for work on the anatoxins. Prizes of the Grand Ecoles. The Laplace Prize to Charles Crussard. The L. E. Rivot Prize to Charles Crussard, Jean Hüe de la Colombe, André Brocard and Bruno Cirilli.
General Foundations for Scientific Research. The Gegner Foundation to Claudius Roux, for his work on natural science and the history of science. The Hirn Foundation to Marcel Fouché, for his work in acoustics. The Henri Becquerel Foundation to André Savornin, for his work in terrestrial magnetism.

\section{The Loutreuil Foundation}

Researches on Fixed Questions. Henri Erhart $(5,000$ francs $)$, for the extension of his pedological researches. Albert Henry (3,000 francs), for his researches on parasitism of the mammary gland. Louis Nattan-Larrier (6,000 francs), for the study of the serological conditions of the development of normal tissues and of cancers. Paul Vayssière (3,000 francs), for work on the disinfection and preservation of agricultural products.

Researches to be Carried out in French Colonies. Lucien Berland (8,000 francs), for researches on the entomological fauna of the upper regions of the atmosphere, especially in Senegal. Henri Humbert $(6,000$ francs), as a contribution to a new botanical expedition in southern tropical Africa and in the north-west of Madagascar.

For Laboratory Equipment. Zéphirin Carrière (10,000 francs), for the purchase of an electrical apparatus for the analysis of sound. Institut national agronomique (10,000 francs), for the purchase of $a$ microscope for the examination of fluorescence by production of ultra-violet rays. Casimir Monteil (5,000 francs), for the purchase of a petrol motor for brake measurements. Henri Thiel (2,000 francs), for the purchase of a Nistri stereographometer.

Publications. Comité de Physique du Globe des Colonies (10,000 francs), for the publication of the "Annales de Physique du Globe de la France d'outremer". Fédération française des sociétés de sciences naturelles (4,000 francs), for the publication of the "Fauna de France". Henri Gaussen (5,000 francs), for the publication of a memoir by Charles Flahault on the flora of the French Mediterranean region. Marc Simonet (4,000 francs), for the publication of sixteen coloured plates of certain hybrids of Iris. Société Linnéenne de Lyon (3,000 francs), for the publication of library catalogues.

Libraries. Ecole nationale vétérinaire d'Alfort (8,000 francs), for preparing a card catalogue and completing its foreign periodicals. Ecole nationale vétérinaire de Lyon (7,000 francs), for the purchase of foreign veterinary works. Ecole nationale vétérinaire de Toulouse (7,000 francs), for the purchase of French and foreign veterinary works. Ecole polytechnique (5,000 francs), for the purchase of scientific publications. Institut national agronomique $(5,000$ francs), for the purchase of foreign periodicals. Société astronomique de France (2,000 francs), for increasing its collection of lantern slides. Société d'encouragement pour l'industrie nationale $(8,000$ francs), for the purchase of foreign works.

\section{MME. Victor NouRy Foundation}

Edgar Aubert de La Rüe, for his explorations in the French Colonies; Albert Berthelot, for the whole of his studies; Maurice Bouvet, for his work on the history of pharmacy in France; Gilbert Ranson, for his memoir on the medusæ collected during the vovages of Prince Albert I of Monaco ; Constantin Toumanoff, for his studies relating to antipaludism in Asia (2,500 franes each). 


\section{General Foundations}

The Henry Le Chatelier Foundation to Léon Guillet, for his studies on zirconium and beryllium. The Millet-Ronssin Foundation to Justin Savornin (4,000 francs), for his geological work in Algeria; Paul Remy (3,000 francs), for the whole of his zoological work and especially that on insects; Robert Kühner (3,000 francs), for his researches on Basidio. mycetes.

\section{VILLEMOT FOUNDATION}

Mme. Rose Bonnet-Sainturier (15,000 francs), for the publication of a memoir on the double stars. Lucien Cayeux (15,000 francs), for the purchase of a polarizing microscope and various other instruments. Aimé Cotton (40,000 francs), for the electromagnet laboratory. Alexandre Dauvillier (12,000 francs), for a recording electrometer. Jean Goarnisson $\{5,000$ francs), for the establishment of a laboratory for the preparation of certain remedies against leprosy and sleoping sickness. Edouard Legé (53,000 francs), for experimenting, on a semi-industrial scale, on the synthetic preparation of motor petrol from certain colonial seeds. Charles Maurain (15,000 francs), for researches on terrestrial magnetism and atmospheric electricity. Marin Molliard (5,000 francs), for researches on the morphogenic and physiological action on plants of atmospheric gases under varying pressures. Albert Peyron (8,000 francs), for the development and publication of his studies in comparative pathology relating to tumours. Maurice Piettre (10,000 francs), for the installation of a lowtemperature room at the Halles. Gustave Ribaud $(10,000$ francs $)$, for the experimental study by various methods of the heat losses through the walls of furnaces. Hyacinthe Vincent (12,000 francs), for the purchase of laboratory animals and material for continuing his researches on immunity and pathology of infectious diseases.

\section{Special Foundations}

The Lannelongue Foundation to Mme. Gabriel Cusco. The Girbal-Baral Foundation (each 10,000 francs) to Daniel Bouttier and Julien Jouin. The d'Aumale Prize Grants of 5,000 francs each to the widows of Joannès Chatin and Jean Charcot.

\section{Science News a Century Ago}

\section{Russian North Polar Expeditions}

UNDER the above title, the Athenceum of January 27 gave a long account of the exploration of the coasts of Novaya Zemlya based on the memoirs of von Baer contributed to the Imperial Academy of Sciences, St. Petersburg. After referring to the earliest voyages to the north, the writer of the review said: "During the years 1819-24 five well equipped expeditions were despatched by the Russian government for the Survey of Novaïa Semlïa, four of which were under the command of the experienced navigator Lütke; yet they all failed in the especial object of their mission, namely, to trace the eastern coasts of that country." In 1832 a merchant of Archangel nemed Brandt, equally alive to the interests of science and of commerce, formed a company, and despatched one ship commanded by Lieut. Krotoff to sail along the west coast of the islands and a second in command of the pilot Pachtussoff to survey the eastern coasts. A third vessel sent to the western coast in search of walrus returned richly laden. Lieut. Krotoff and his ship were lost, but Pachtussoff and his party wintered in the north and made valuable surveys.

In 1834 the Russian Government fitted out two vessels, one commanded by Pachtussoff and another by Ziwolka. Leaving Archangel in July, Pachtussoff was away about a year and died shortly after his return. "The two expeditions conducted by Pachtussoff," said the Athenoum, "produced a mass of meteorological observations of a very valuable kind, and which bear uniquivocal testimony to the carefulness and assiduity of that officer." The greatest cold experienced in Novaya Zemlya was in February, when the thermometer fell to $-40^{\circ}$. It often remained for days together at $-34^{\circ}$.

Karl Ernst von Baer was born in Esthonia on February 17, 1792, and studied medicine at Dorpat. Finding that his native country presented indifferent prospects for a naturalist, he went to Germany and became professor of zoology at Könisberg, where he founded a Zoological Museum. In 1834 he was appointed librarian to the Imperial Academy of Sciences, in which situation he made use of his opportunities to collect information regarding the polar regions of the Russian Empire. He had previous to this become famous for his discovery of the mammalian ovum, which led to his being regarded as the founder of comparative embryology. His death took place at Dorpat on November 28, 1876.

\section{The Zoological Society}

AT a meeting of the Zoological Society held on January 23, 1838, Richard Owen being in the chair, Mr. Ogilby characterized several new species of mammals contained in the collection made by Captain Alexander in South Africa, and Mr. Gould described several new and interesting birds included in the collection. Among them was an eagle with a white breast and red tail ; two small falcons, scarcely exceeding in size the English house-sparrow ; and a very small owl of scarcely larger size. There was also a jay of very gaudy plumage which perches upon the horns of rhinoceros, supposedly for the purpose of obtaining insects; the hunters of the rhinoceros anxiously watch this bird, as when they see it fly up from the horn they know that the animal is alarmed. At the same meeting, Owen read some observations on the anatomy of the giraffe, from dissections made of the animals which died at the Regent's Park and Surrey Zoological Gardens.

\section{The Morse Telegraph}

"A NEW and improved transmitting and recording apparatus was completed for Prof. Morse by his partner, Mr. Alfred Vail, of the Speedwell Iron-works, near Morristown, N.J., at the close of the year 1837; and early in January, 1838, Prof. Morse first discarded the numeral signs for words, and employed a true alphabet of 'dots and dashes'. The first exhibition of an alphabetic record of words and sentences took place in the New York City University, on January 24,1838 , through ten miles of wire wound on reels. The New York Journal of Commerce, in a notice of this performance, remarked, 'Professor Morse has recently improved on his mode of marking, by which he can dispense altogether with the telegraphic dictionary, using letters instead of numbers"." ("A Memorial of Joseph Henry", p. 384.) 